2 Oliver $W$. Account of the effects of camphor in a case of insanity. London Medical fournal $1785 ; 6: 120-30$.

3 Sargent WW, Slater E. An introduction to physical methods of treatment in psychiatry. 5 th ed. Edinburgh: Churchill Livingstone, 1972.

+ Showalter E. The female malady: women, madness and English culture. London: Virago, 1987:138. 5 Fink M. Meduna and the origins of convulsive therapy. Am f Psychiatry 1984;141:1034-41.

6 Kalinowsky L. The history of electroconvulsive therapy. In: Abrams R, Essman WB, eds. Electroconvulsive therapy, biological foundations and clinical applications. Lancaster: MTP Press, 1982:1-5.

7 Kalinowsky L. Electroconvulsive therapy in schizophrenia. Lancet 1939;ii:1232-3.

8 Protheroe C. Puerperal psychosis: a long term study 1927-61. Brf Psychiatry 1969;115:9-30.

9 Platz C, Kendell RE. A matched control follow-up and family study of "puerperal psychoses." Br f Psychiatry 1988;153:90-4.

10 Taylor PJ, Fleminger JJ. ECT for schizophrenia. Lancet 1980;i:1380-3.

11 Greenblatt $M$, Grosser $\mathrm{GH}$, Wechsler $\mathrm{H}$. Differential response of hospitalised depressed patients to somatic therapy. Am F Psychiatry 1964;120:935-43.

12 Medical Research Council Clinical Psychiatric Committee. Clinical trial of the treatment of depressive illness. Br Med f 1965; i:881-6.

13 Freeman CPL, Basson JV, Crichton A. A double blind controlled trial of electroconvulsive therapy ECT) and simulated ECT in depressive illness. Lancet 1978; ; $7338-40$.

14 West E. Electric convulsion therapy in depression. A double controlled trial. Br Med $\mathrm{f}$ $1981 ; 282: 355-7$
15 Gregory S, Shawcross CR, Gill D. The Nottingham ECT study: a double blind comparison of hilateral, unilateral and simulated ECT in depressive illness. Br f Psychiatry 1985;146:520-4. 16 Lambourn J, Gill D. A controlled comparison of simulated and real ECT. Br J Psychiatry 1978;133:514-9.

17 Johnstone EC, Deakin JFW, Lawler P, et al. The Northwick Park ECT trial. Lancet 1980;ii: $1317-20$.

18 Kendell RE. The present status of electroconvulsive therapy. Br f Psychiatry 1982;139:265-83.

19 Essman WB. Electroconvulsive shock and cerebral chemistry: changes and sequelae. In: Abrams R, Essman WB, eds. Electroconvulsive therapy, biological foundations and clinical applications. Lancaster: MTP Press, 1982:199-224.

20 Green AR, Heal DJ, Grahame-Smith DG. Further observations on the effect of repeated electreconvulsive shock on the behavioural responses of rats produced by increases in the functional activity of brain 5-hydroxytryptamine and dopamine. Psychopharmacology 1977;52: 195-200.

21 Modigh K. Electroconvulsive shock and post-synaptic catecholamine effects: increased psychomotor stimulant action of apomorphine clonidine in resperpine pre-treated mice by repeated ECS. I Neural Trans 1975;36:191-232.

22 Pandey GN, Heinze WJ, Brown BD, Davis JM. Electroconvulsive shock treatment decreases $\beta$ adrenergic receptor sensitivity in rat brain. Nature 1979;280:234-5.

23 Slade. AP, Checkley SA. A neuroendocrine study of the mechanisms of action of ECT Brf Psychiatry 1980;137:217-21

24 Post F. Then and now. Br f Psychiatry 1978;133:83-6.

\title{
DF-2 infection
}

\section{May follow dog bites and hazardous to the immunosuppressed}

DF-2 (dysgonic fermenter type 2) is the designation assigned by the Centers for Disease Control, Atlanta, to a slow growing, non-motile, pleomorphic, Gram negative bacillus first identified in 1973. Four years later Butler implicated this organism in "a new disease of man": a septicaemia that is associated with exposure to animals and pre-existing illness, particularly splenectomy and alcohol abuse, and that is often fatal.' Thus far 52 cases of DF-2 infection in man have been described in reports published in English. ${ }^{2}$ Most have come from the United States. Only four cases have been notified to the Public Health Laboratory Service in Britain (N Barrett, PHLS Communicable Disease Surveillance Centre, personal communication). DF-2 infection must, however, be more common than these reports suggest.

DF-2 infections have been reported world wide, ${ }^{2}$ and all ages seem to be vulnerable. ${ }^{3}$ Epidemiological evidence shows that it is a zoonotic infection-over three quarters of patients have been exposed to dogs, although only two thirds of them have had a penetrating injury. Cats ${ }^{4}$ and wild animals ${ }^{1}$ have also been implicated. DF-2 is part of the normal oral flora of healthy dogs ${ }^{5}$ and has been isolated from the mouth of a dog whose bite resulted in DF- 2 infection. ${ }^{6}$

DF-2 is an opportunistic pathogen of low virulence. ${ }^{7} \mathrm{~A}$ third of patients with the infection have had splenectomies, a quarter are alcoholics, and $15 \%$ have chronic respiratory disease. ${ }^{2}$ Subjects whose immune systems are suppressed are also vulnerable.

The clinical consequences of DF-2 infection range from the indolent to the rapidly catastrophic; overall, a quarter of reported patients have died. Most commonly it causes a severe community acquired septicaemia that affects many organs. Patients commonly suffer disseminated intravascular coagulation, endocarditis, pneumonia, purulent meningitis, ${ }^{12}$ and symmetrical peripheral gangrene (often requiring amputation). ${ }^{8}$ Oligoarticular arthritis, ${ }^{9}$ myocardial infarction, ${ }^{10}$ brain abscess, and membranoproliferative glomerulonephritis ${ }^{11}$ have also been reported. In those who were previously healthy - that is, about a fifth of all casesinfection may be less dramatic, but deaths have occurred..$^{12}$

A confluent, blanching, maculopapular rash is often seen, ${ }^{1+}$ and petechiae may indicate a coagulopathy. A necrotising eschar at the site of injury may be characteristic, ${ }^{815}$ but cellulitis is more common. Inoculation of DF-2 into the eye has resulted in corneal perforation ${ }^{16}$ and angular blepharitis ${ }^{17}$ without systemic disturbance.

DF-2 has been isolated mostly from blood cultures, but also from cerebrospinal fluid and conjunctival swabs. ${ }^{17}$ Gram staining of the buffy coat has allowed early diagnosis particularly in patients who have had a splenectomy. ${ }^{18}$ The organism is difficult to culture and detect by standard methods because of its slow growth and fastidious requirements. ${ }^{18}$ Reliance on conventional techniques may therefore result in it being missed altogether, discarded as a contaminant, or misidentified. DF-2 is sensitive to most antibiotics but - unusually for a Gram negative bacterium - is resistant to aminoglycosides. ${ }^{118-20}$ Penicillin $\mathrm{G}$ is the best treatment.

There are about 200000 dog bites in Britain each year, ${ }^{21}$ and yet reports of DF-2 infection remain rare. Considerable underdiagnosis seems likely because of difficulties in isolating the organism, the widespread use of penicillin in the early management of dog bites, and the empirical treatment with antibiotics of patients with septicaemia in whom the causative organism is not identified.

DF-2 infection is a particular hazard to patients who are immunocompromised and those who have had a splenectomy, and such patients should be made aware of the dangers of keeping pets. Although the clinical features are usually nonspecific, a history of animal contact and the well established predispositions should suggest the diagnosis. As the interval between injury and presentation may be up to two weeks, however, the history of animal exposure is easily overlooked and with it a vital clue to the diagnosis. If DF-2 infection is considered possible the laboratory needs to be told so that the organism is specifically sought. As laboratory confirmation is often delayed, however, prompt empirical treatment may have to be started on clinical suspicion alone.

Clinical Lecturer,

MARK MCCARTHY

Medical Unit,

The London Hospital,

London E1 1BB

Senior Registrar,

ALIMUDDIN ZUMLA

Department of Clinical Immunology,

Hammersmith Hospital,

London W12 0HS 
1 Butler T, Weaver RE, Ramani TK, et al. Unidentified gram-negative rod infection. A new disease of man. Ann Intern Med 1977;86:1-5.

Zumla A, Lipscomb G, Corbett $M$, McCarthy $M$. Dysgonic fermenter type 2: an emerging zoonosis. Two case reports and review. $Q \mathcal{F}$ Med 1988 (in press).

Dankner WM, Davis CE, Thompson MA. DF-2 bacteremia following a dog bite in a 4-month old child. The Pediatric Infectious Disease foumal 1987;6:695-6.

4 Carpenter PD, Heppner BT, Gnann JW. DF-2 bacteremia following cat bites. Am $\mathcal{f}$ Med $1987 \cdot 82 \cdot 621-3$

5 Bailie WE, Stowe EC, Schmitt AM. Aerobic bacterial flora of oral and nasal fluids of canines with reference to bacteria associated with bites. $\mathcal{F}$ Clin Microbiol 1978;7:223-31.

Chan PC, Fonseca K. Septicaemia and meningitis caused by dysgonic fermenter-2 (DF-2). 9 Clin Pathol 1986;39:1021-4.

7 Butler T, Johnston KH, Gutierrez Y, Aikawa M, Cardaman R. Enhancement of experimental bacteremia and endocarditis caused by dysgonic fermenter (DF-2) bacterium after treatment with methylprednisolone and after splenectomy. Infect Immun 1985;47:294-300.

8 Findling JW, Pohlmann GP, Rose HD. Fulminant gram-negative bacillemia (DF-2) following a dog bite in an asplenic woman. Am $\mathcal{F}$ Med 1980;68:154-6.

9 Schoen RT, Wohlgelernter D, Barden GE, Swartz TJ. Infection with CDC Group DF-2 gramnegative rod. Report of two cases. Arch Intern Med 1980;140:657-8.

10 Newton NL, Sharma B. Case report: acute myocardial infarction associated with DF-2 bacteremia after a dog bite. $A m \mathcal{F}$ Med Sci 1986;291:352-4.
11 Archer SL. Dysgonic Fermenter 2 infection resulting in chronic glomerulonephritis. Can Med Assoc $\mathcal{F}$ 1985; 132:657-60.

12 Pers C, Kristiansen JE, Scheibel JH, Eskildsen PC, Jensen F, Jensen E. Fatal septicaemia caused by DF-2 in a previously healthy man. Scand f Infect Dis 1986;18:265-7.

13 Howard AJ, Hughes M, Parry H, Roberts JG. Dog bites and dysgonic fermenting organisms. Lancet 1983;ii:1022-3.

14 Westerink MA, Amsterdam D, Petell RJ, Stram MN, Apicella MA. Septicaemia due to DF-2. Cause of a false-positive cryptococcal latex agglutination result. Am $\mathcal{f}$ Med 1987;83:155-8.

15 Kalb R, Kaplan MH, Tenenbaum MJ, Joachim GR, Samuels S. Cutaneous infection at dog bite wounds associated with fulminant DF-2 septicaemia. Am 7 Med 1985;78:687-90.

6 Kiel RJ, Crane LR, Aguilar J, Palutke WA, Cowden JW. Corneal perforation caused by dysgonic fermenter-2. JAMA 1987;257:3269-70.

17 Glasser DB. Angular blepharitis caused by gram-negative bacillus DF-2. Am fo Ophehalmol 1986;102:119-20.

18 Hicklin H, Verghese A, Alvarez S. Dysgonic Fermenter 2 septicemia. Rev Infect Dis 1987;9: $884-90$.

9 Schlossberg D. Septicemia caused by DF-2. f Clin Microbiol 1979;9:297-8.

20 Worthington $M$, Gleason T, Pandian NG, Daly B. Tricuspid valve myxoma infected with dysgonic fermenter-2. South Med $\mathcal{F}$ 1984;77:241-2.

21 Baxter DN. The deleterious effects of dogs on human health: dog associated injuries. Community Med 1984;6:29-36.

\section{Defence societies' price war}

\section{May lead to crown immunity}

The Medical Defence Union recently settled a claim over a brain damaged baby born in 1965 for $£ 550000$, more than its entire income in that year. The defence societies' subscription in 1965 was $£ 3$ a year. This year it is $£ 1080$. Now the outbreak of a price war between the two main doctors' defence organisations, the Medical Defence Union and the Medical Protection Society, looks set to bring the issue of the escalating cost of paying for doctors' mistakes to a head. The government has turned down the BMA's proposal for a no fault compensation pilot scheme and shows no signs of agreeing to refer the issue to a select committee, which has also been urged by the BMA.

Talks among the BMA, the defence bodies, and the Department of Health have been going on for some time, but the Medical Protection Society's move in introducing differential subscriptions from next April-spurred by the entry into the market of commercial insurers offering lower rates for general practitioners and other lower risk doctors (22 October, p 1001)-will force the problem further up the agenda. The Medical Defence Union's decision to retain a flat rate subscription, increased by only $25 \%$ to $£ 1350$ from next January, must raise concern about its ability to meet projected claims, though the union says this was the "lowest prudent single rate" its actuaries advised it could charge.

The Medical Protection Society claims its proposed new rates-around $£ 1000$ for general practitioners and low risk hospital doctors, $£ 1800$ for high risk hospital doctors and surgeons, such as anaesthetists and orthopaedic surgeons, and $£ 4000$ to $£ 5000$ for obstetricians - "accord with its actuarial and other professional advice." The new rates will take effect next April unless the government steps in. As one possible solution the society is calling for a no fault scheme for brain damaged babies, who account for $40 \%-50 \%$ of the money paid in compensation.

At present, general practitioners have their subscriptions fully refunded in arrears, through their expenses, though they still have to find the money at first. Hospital doctors working full time for the National Health Service have two thirds of their subscriptions paid by the government under an agreement which runs until December 1989.

The BMA has warned that differential rates would have a "disastrous" effect on recruitment to high risk specialties and increase pressures for differential salaries, which the profession has always opposed. One solution would be for subscriptions for hospital doctors to be reimbursed in full less a small amount for advice and help unrelated to negligence claims which the defence bodies provide. The Medical Protection Society would like to see the government reimburse full rate subscriptions for junior doctors, reflecting their higher incidence of mistakes. At present, says the society, concessionary rates for juniors reduce the value of a full rate subscription by $22 \cdot 5 \%$, which means that senior doctors are subsidising juniors.

But the government may well conclude that it would be cheaper and simpler in the long run to introduce crown indemnity for doctors employed by the National Health Service, with health authorities taking over liability from individual doctors. The government already bears much of the cost of the present system. In 1988 it paid some $£ 60 \mathrm{~m}$ towards doctors' defence subscriptions, while compensation, legal, and administrative costs totalled an estimated $£ 15 \mathrm{~m}$ for health authorities and $£ 60 \mathrm{~m}$ for the defence societies, according to a paper from the King's Fund Institute and the Centre for Sociolegal Studies, Oxford.

The profession is against crown indemnity. The fear is that health authorities will settle cases on grounds of expediency, disregarding the interests of the individual doctor. The suggestion has been made that cases such as Sidaway, when the House of Lords decided that a neurosurgeon was not negligent in failing to warn of a less than $1 \%$ risk of paralysis, and Wilsher, in which the law lords ordered a retrial on the issue of causation, might have been settled rather than fought if a health authority had been controlling the litigation.

But plaintiffs' solicitors will testify that health authorities, which now handle litigation concerning nurses and other nonmedical staff, will fight cases as readily as defence societies. The case of Keith Blackburn, who received compensation 12 years after he suffered brain damage from a blocked tracheostomy tube, was one of negligent nursing care strongly defended by health authority solicitors.

A further fear with crown indemnity is that the employing authority will bring pressure to bear on doctors' clinical judgment. The other side of the coin is that it could pave the way for a proper system of medical audit and risk management - so that fewer mistakes are made.

Legal Correspondent, $B M \mathcal{F}$

CLARE DYER

1 Ham C, Dingwall R, Fenn P, Harris D. Medical negligence: compensation and accountability. London King's Fund Institute, 1988. 